\title{
Biology and Management of Tropical Whiteweed (Ageratum conyzoides) in Citrus Groves ${ }^{1}$
}

\author{
Ramdas Kanissery, Brent Sellers, and Steve Futch ${ }^{2}$
}

Tropical whiteweed (Ageratum conyzoides; synonym Eupatorium conyzoides), a member of the Asteraceae plant family, is considered a common weed of agriculture crops, wetlands, roadsides, and pastures in many parts of the world (Kohli et al. 2006; GISD 2016). Other common names for this annual non-native species include billygoat weed, bluebonnet, and bluetop. It is listed as an invasive plant in several plantation crops, including citrus (Holm et al. 1977). Although this species has been documented in Florida since the 1940s, it has recently become problematic in natural areas, pastures and rangeland, and citrus groves. In citrus groves, tropical whiteweed spreads quickly if not managed properly.

\section{Description}

Stem and roots: Stems are erect and branching with soft hairs (pubescent) and grow to a height of approximately 3 feet (Figure 1). The roots are fibrous and shallow (usually not deeper than 4 inches).

Leaves: Leaves are opposite, 0.25 to 4 inches long, 0.2 to 2 inches wide, on 0.2 to 3 -inch-long hairy petioles. Leaf shape is lanceolate to broadly ovate and leaf margins are serrated with coarse teeth (Figure 2). Leaf surfaces are rough and lightly hairy with prominent veins. When crushed, the leaves produce a strong, rancid odor.

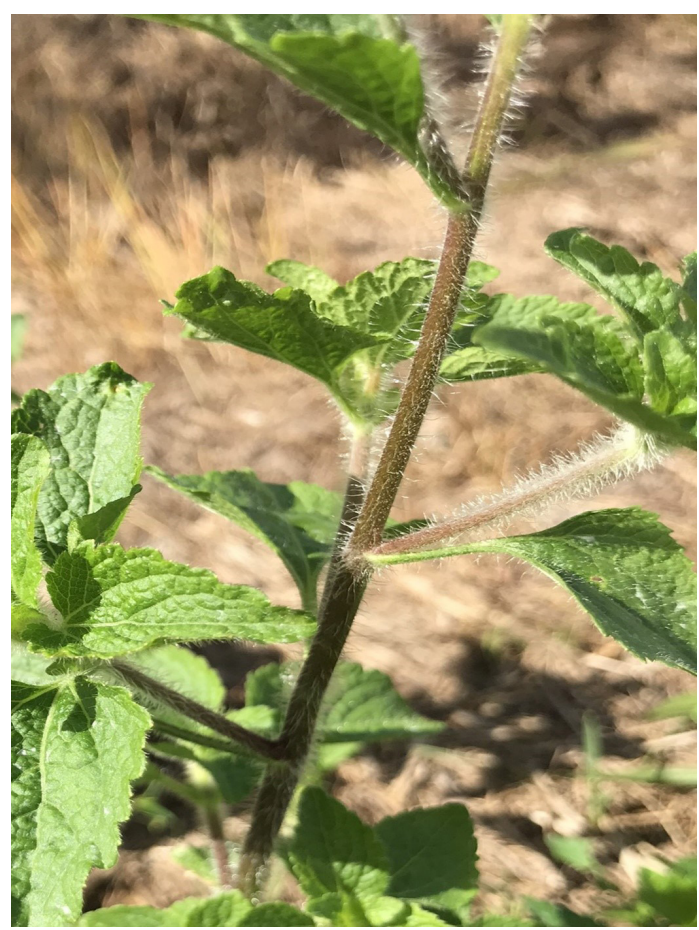

Figure 1. Tropical whiteweed stem.

Credits: Ramdas Kanissery, UF/IFAS

Flowers: Flowers are blue, purple, pinkish, or white colored, less than $6 \mathrm{~mm}$ across, and are produced in close terminal flower heads (Figure 3). Tropical whiteweed flowers yearround when growing conditions are favorable. The fruits are small, brown, one-seeded achenes.

1. This document is HS1325, one of a series of the Horticultural Sciences Department, UF/IFAS Extension. Original publication date January 2019. Visit the EDIS website at https://edis.ifas.ufl.edu for the currently supported version of this publication.

2. Ramdas Kanissery, assistant professor, Horticultural Sciences Department; Brent Sellers, professor and associate center director, UF/IFAS Cattle Range Research and Education Center; and Steve Futch, Extension agent IV, UF/IFAS Citrus REC; UF/IFAS Extension, Gainesville, FL 32611. 


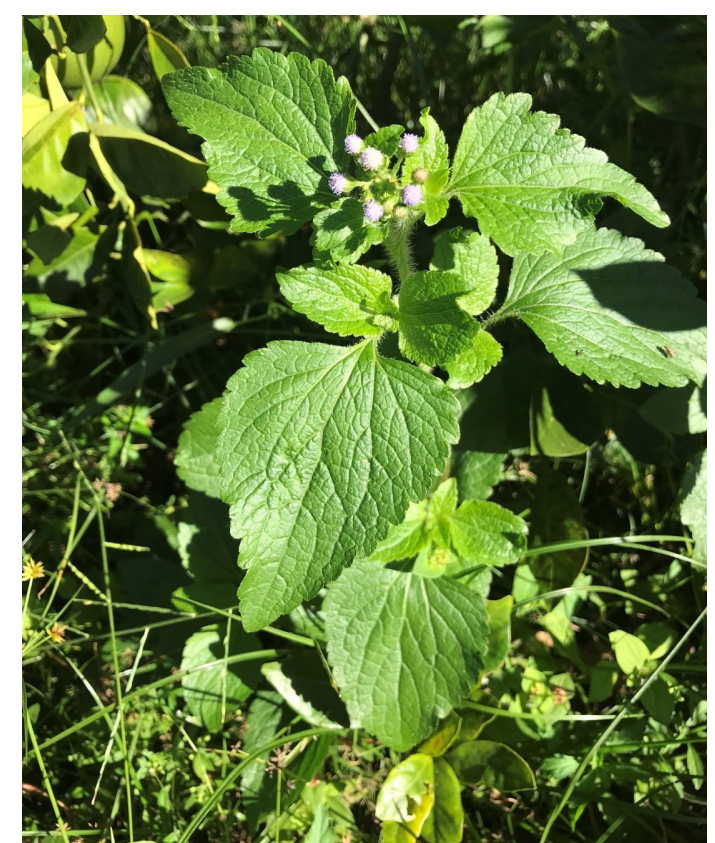

Figure 2. Tropical whiteweed leaves_ovate and serrated. Credits: Ramdas Kanissery, UF/IFAS

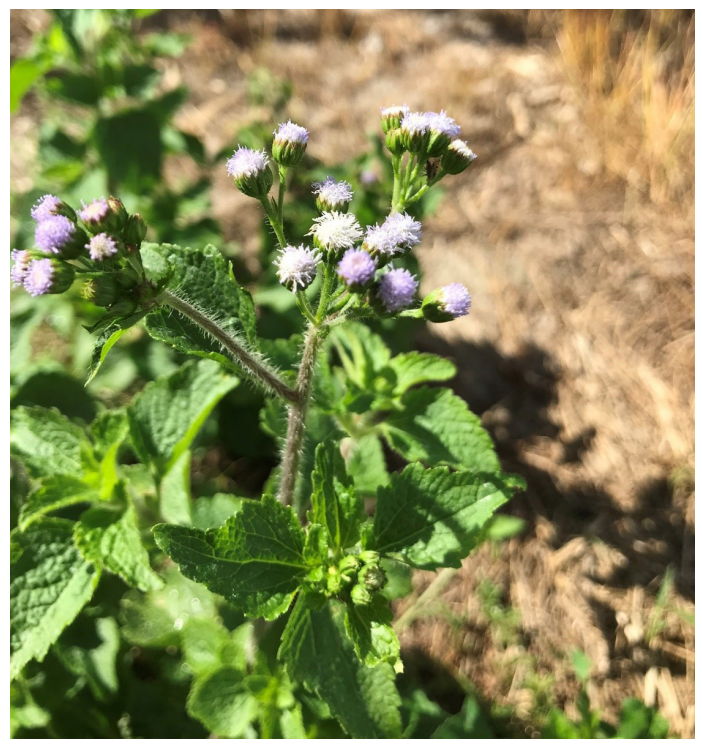

Figure 3. Tropical whiteweed flowers. Note the purplish hue of flowers. Credits: Ramdas Kanissery, UF/IFAS

\section{Life Cycle and Distribution}

Tropical whiteweed is an annual and can complete its life cycle in approximately two months. It grows particularly well and forms dense populations where soil fertility is high, but can survive and reproduce in low-fertility soils. The plant prefers moist soil but also grows in dry areas.

Tropical whiteweed is native to the warmer parts of the southeastern United States, Mexico, the Caribbean, and tropical South America. In Florida, the occurrence of tropical whiteweed is reported from Brevard, Broward, Citrus, Collier, Hardee, Hendry, Leon, Miami-Dade, Palm Beach, Seminole, and St. Lucie counties (Wunderlin et al. 2018).

\section{Similar Species}

Tropical whiteweed closely resembles blue billygoat weed (Ageratum houstonianum) in biology and distribution. The smell of crushed foliage is similar in both species. However, A. houstonianum has larger flower heads (75-100 flowers) compared to tropical whiteweed (30-75 flowers). Tropical whiteweed flowers are often mistaken for Siam weed (Chromolaena odorata) flowers, but the latter are usually pale pink or dark purple in color, and sometimes turn whitish when older. Unlike the other two species, Siam weed is a perennial species.

Tropical whiteweed flowers also resemble the flowers of Cape Sable whiteweed (Ageratum littorale), an endangered plant species in Florida. A. littorale stems are shorter (less than 2 feet) and leaves are much smaller (less than 1.5 inches) and narrower than tropical whiteweed. For a complete list of Florida's regulated plant species, visit http://www. flrules.org/gateway/ruleno.asp?id=5B-40.0055\&Section $=0$.

\section{Economic and Environmental Impacts}

Tropical whiteweed is a significant weed in many crops in the tropics and subtropics. Warm weather provides a conducive environment for proliferation of this weed. Yearround flowering and abundant seed production allows high proliferation of this weed, often carpeting the soil where conditions are favorable (Figure 4). Yield reductions due to tropical whiteweed infestation have been reported from a wide array of crops (Kohli et al. 2006; Wezel 2000). Tropical whiteweed is also reported as a host of economically important crop pathogens and pests, and has been found to inhibit the growth of other plant species by releasing allelochemicals to the soil (GISD 2016; Dogra et al. 2009).

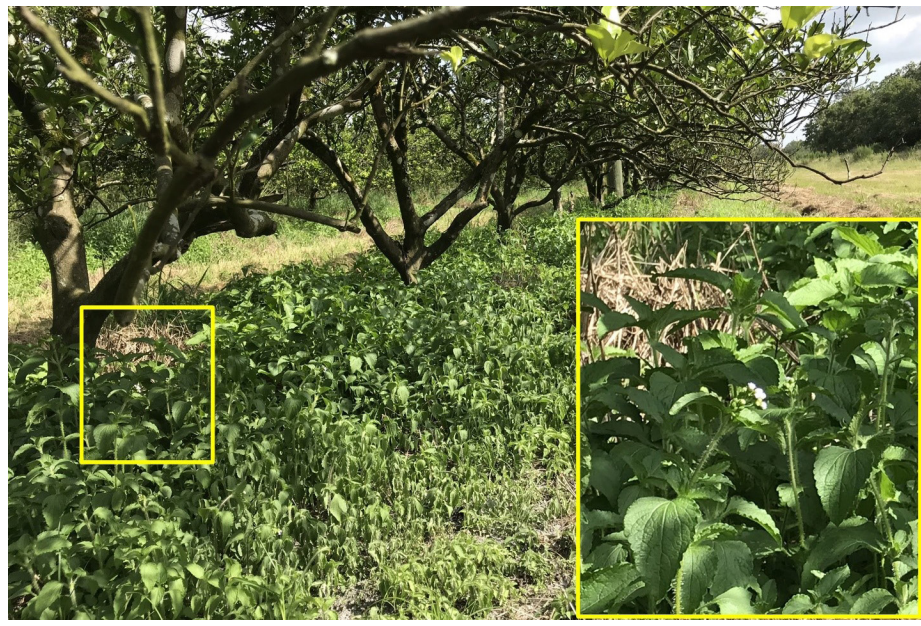

Figure 4. Heavy infestation of tropical whiteweed in citrus tree rows in a citrus grove in Hendry County, FL.

Credits: Ramdas Kanissery, UF/IFAS 


\section{Management}

\section{Cultural and Physical Control}

The primary mode of reproduction for tropical whiteweed is through seeds, which are easily dispersed by wind, water, animals, people, machinery, and vehicles. Hence, management efforts should focus on prevention and sanitation. Managing this weed before it sets seed will reduce future infestations. Mechanically controlling tropical whiteweed is relatively easy, as it is shallow-rooted.

\section{Chemical Control}

Post-emergent herbicides like paraquat (Singh et al. 1996) and glyphosate (Kumar and Singh 1989) will effectively control emerged tropical whiteweed. However, these herbicides are most effective when weeds are young and actively growing. Thorough spray coverage is required for control of emerged weeds. Also, application has to be made prior to flowering to prevent the formation of a seed bank in the soil. Simazine, a residual herbicide used in citrus, has also been reported to give good control on the emergence of tropical whiteweed (Gautam and Chauhan 1984).

For more information on the recommended rates of herbicides labeled for use in citrus, please see Florida Citrus Production Guide, Chapter 37: Weeds (www.crec.ifas.ufl. edu/extension/pest/PDF/2017/Weeds.pdf).

Also, refer to the EDIS publication Maximizing Weed Control in Florida Citrus (http://www.edis.ifas.ufl.edu/ hs237) for more information on weed control in Florida citrus.

\section{References}

Dogra, K. S., R. K. Kohli, S. K. Sood, and P. K. Dobhal. 2009. "Impact of Ageratum conyzoides L. on the diversity and composition of vegetation in the Shivalik hills of Himachal Pradesh (Northwestern Himalaya), India." International Journal of Biodiversity and Conservation 1(5): 135-145.

Gautam, D. R. and J. S. Chauhan. 1984. "Possibilities of reducing the soil cultivation by using herbicides in peach nursery production." Journal of Tree Sciences 3(1/2): 99-104.

GISD. 2016. "Global Invasive Species Database (GISD)." http://www.issg.org/database

Holm, L. G., D. L. Plucknett, J. V. Pancho, and J. P. Herberger. 1977. The World's Worst Weeds. Distribution and Biology. Honolulu, Hawaii, USA: University Press of Hawaii.
Kumar, S. and C. M. Singh. 1989. "Control of Ageratum conyzoides L. under Mid Hill Conditions of Himachal Pradesh.” Indian Journal of Weed Science 21(1, 2): 55-59.

Kohli, R. K., D. R. Batish, H. P. Singh, and K. S. Dogra. 2006. "Status, invasiveness and environmental threats of three tropical American invasive weeds (Parthenium hysterophorus L., Ageratum conyzoides L., Lantana camara L.) in India." Biological Invasions 8(7): 1501-1510.

Singh, C. M., N. M. Angras, and S. Kumar. 1996. Weed Management. New Delhi, India: MD Publications.

Wezel, A. 2000. "Weed vegetation and land use of upland maize fields in north-west Vietnam." GeoJournal 50(4): 349-357

Wunderlin, R. P., B. F. Hansen, A. R. Franck, and F. B. Essig. 2018. "Atlas of Florida Plants." http://florida.plantatlas.usf. edu/ 